of police commissioners appointed and removable by the governor; the mayor is ex-officio member of the board. Several bills have been introduced to replace these boards by locally selected officials. The bill which stands the most likelihood of becoming law, and which has passed the lower house, provides for a single police commissioner in each city, to be appointed by the mayor, though subject to removal by the governor-as well as by the mayor- "wherever the public interest requires." The powers vested in the commissioner over the administration and discipline of the police department are similar to those exercised by the police commissioner of New York City. A bill providing for a like tenure of the excise commissioner in St. Louis has also passed the lower house; this officer is at present appointed and removable by the governor.

Harvard University has recently received from Mr. F. G. Thomson of Philadelphia a guarantee of the sum of $\$ 5000$ a year for ten years, the gift to be used for the extension of instruction in municipal government.

\title{
Present Status of Ballot Laws in the United States
}

\section{ARTHUR LUDINGTON}

It is just twenty years this winter since the adoption of the first "Australian ballot". laws in the United States." A summary of the various ballot laws now in force in the several States is, therefore, of particular interest at this time, as showing the extension of the Australian system in this country at the close of its second decade.

At present, ${ }^{2}$ out of the forty-six States and two territories in the United States proper, thirty-nine States and the territory of Arizona have adopted an official "blanket"3 ballot, printed at public expense, for virtually all elections (not including within that term primary

${ }^{1}$ The law of Mass. was passed in 1888, but did not go into effect until November 1, 1889. No other Australian ballot laws were passed before 1889 .

2 The following statistics in reyard to the ballot laws of the several Statesapply to these laws as they were in force at the date of the last general election, November $3,1908$.

"By a "blanket" ballot is meant one on which are grouped, according to any one of several methods of arrangement, the names of all candidates for any office or group of offices covered by the ballot in question, who have been duly nominated by any political party or body of voters. 
elections). ${ }^{4}$ Such ballots are distributed to the voters only at the polling place, and by the election officers. It is usually expressly provided that no other ballots shall be received by the election officers, or counted, in any election to which the general ballot law applies; but in case the official ballots for any polling place are lost, or for any reason are not on hand, it is often provided that other official ballots may be prepared, as much like the official ballots as possible, and used in their stead. Tennessee has adopted a ballot law of this type for all elections in counties of over 50,000, and towns of over 2500 inhabitants, and in certain other counties to which this law has been applied by special acts-a total of 224 out of 1567 election districts, and these the most densely populated. In all other districts the ballots are unofficial, and separate for each party, the law merely establishing certain requirements as to size and form.

Of the remaining States, Missouri and New Jersey-as well as the territory of New Mexico-have laws which provide that all ballots shall be official and printed at public expense, but that separate ballots shall be printed for each party, containing in each case only the names of the candidates nominated by that one party. In Missouri these ballots are distributed to the voters only at the polling place and by the election officers. Each voter receives, on entering, one ballot of each party, takes these ballots to the voting booth, marks whichever one he selects, folds them all so that only the outside--which is the same on all ballotsis visible, and returns them to the election officer. The ballot which he has voted is then placed in the ballot-box, and the unvoted ballots are deposited in a separate box. ${ }^{5}$ In New Jersey, on the other hand, the official ballots may be, and usually are, distributed to the several party organizations and to individual voters, at least seven days before the election, by the officers charged with the duty of printing them, on pay-

- Elections for school officers, road overseers, officers of fire departments, etc. and sometimes elections of town officers, are usually exempted from the provisions of the general ballot law of the State. In some cases this exemption only applies when such elections are held at a different time from national, State, district, county or municipal elections. In a number of States there are separate ballots, of the type prescribed by the general ballot law, for local and municipal elections, and often for constitutional amendments and other questions submitted to popular vote. The State constitutions, however, almost all contain a provision that all elections by the people shall be by ballot-i.e., of one sort or another.

"Prior to 1897 Missouri had a "blanket" ballot, but in that year the law was amended to provide for separate official ballots for each party. Most of the other features of the old Australian ballot law were, however, retained. 
ment by such party organizations or individual voters of the cost of printing. It is the party organizations that usually take advantage of this provision, and they are furthermore allowed to alter the ballots so secured by erasing the names of any of the candidates, or by the use of pasters of a certain prescribed form. They then distribute these ballots to the voters before the election, and the latter prepare them, take them with them to the polling place, and deliver them (just as in the old days before the Australian ballot system had ever been adopted in this country), seldom making use of the ballots offered to them by the election officers. The one redeeming feature of this system is the use of official envelopes which can only be procured at the polling place, from the election officers. Every ballot cast must be enclosed in such an envelope. Even with this provision, however, a commission, appointed by the State senate in 1907 to investigate the use of paper ballots and voting machines in the State, reported to the legislature in 1908 that the ballot now used was, "with perhaps a single exception, the most unsafe, the farthest removed from a secret ballot, and the most easily manipulated in the interests of fraudulent voting of any paper ballot in use in any northern State."

In New Mexico, likewise, the law allows the distribution of the official ballots to the voters by the several party organizations prior to the day of election.

The other four States, besides Missouri, New Jersey, and the territory of New Mexico, which have not yet adopted an official blanket ballot, are Connecticut, the two Carolinas and Georgia. The first of these, Connecticut, occupies a position-so far as its form of ballot is concerned - midway between Missouri, New Jersey and New Mexico on the one hand, and the Carolinas and Georgia on the other. Properly speaking, it has no official ballots, since each party prints its own, and distributes them to the voters. The secretary of state, however, prepares blank forms of the proper size and shape, and has printed on the back of each the words "official ballot;" and, in addition to this, when furnishing these blank forms to the several parties, he prescribes the size and style of the type to be used in printing the face of the ballot, certain other rules as to form and arrangement being prescribed in the law itself. The party organizations pay the cost of preparing the blank forms thus obtained. The names of the candidates of any party for national and State offices must be printed on one ballot, the names of its candidates for local offices on another, proposed constitutional amendments on a third, and questions in regard to education on a fourth; and all these bal- 
lots, or as many of them as the voter chooses to cast, must be placed by him, while in the voting booth, in an official envelope (similar to those used in New Jersey) obtainable only at the polling place and from the election officers. ${ }^{\circ}$ Unlike the New Jersey system, the envelope must be sealed before being returned to the election officers and deposited. It will be seen that-apart from the fact that in New Jersey the printing of the whole ballot is done under government direction, whereas in Connecticut the face of the ballot is printed under the direction of the several parties, according to rules laid down by the government-- the two systems are essentially alike. Under the latter it is provided, under the former merely permitted, that the ballots be placed in the hands of the several party organizations for distribution to the voters prior to election day. The New Jersey system seems slightly more in accord with the spirit of the true Australian ballot, but the freedom accorded the several parties to alter the official ballot, by pasters and otherwise, goes far to nullify in practice this formal advantage.

The ballot laws of North Carolina, South Carolina and Georgia are one stage farther removed from the Australian system, and may fairly be described as rudimentary. They are essentially a survival from, and represent, the period prior to 1889 ,- - though even at that time many States had ballot laws of a more advanced type. In the two Carolinas the entire preparation and distribution of ballots is left to the rotersin practice, that is, to the party organizations. Their size, form and color are prescribed rather carefully, so that all ballots may be exactly alike on the outside:-In North Carolina the State and county boards of elections are authorized to prescribe rules governing these matters once every two years. The ballots in each State may be printed, or written, or partiy printed and partly written; and must contain no ornament, device, symbol or mark of any sort except the names of the offices to be voted for, and the names of the candidates. In South Carolina there are eight separate ballots for various sets of offices, and another ballot for questions submitted to popular vote; and for each sort of ballot there is a separate ballot-box. In North Carolina there are five separate ballots provided for, each with its own ballot-box. Of the two, the law of South Carolina is somewhat the more advanced.

The law of Georgia stands in a class by itself in its almost complete lack of any provisions regulating the form of ballot. A paragraph in the constitution (art. 2, sec. 1, par. 1) providing that "in all elections by the

- This feature, of the official envelope, is found only in the laws of these two States. 
people the electors shall vote by ballot," a section of the code to the same effect, and another subdivision of the same section (code of 1895, title 2, chap. 3, art. 3, sec. 72) to the effect that "as each ballot is received, the number of the voter on the list shall be marked on his ballot before being deposited in the box" (sic!), seem to constitute, between them, the whole law of the State upon this subject.

It is to be noted that, under the laws of Georgia, the two Caroinas and, apparently, New Mexico, the voter prepares his ballot completely before coming to the polling place, and, on arriving there, merely "deposits" it without retiring to a voting booth or any place screened off from public view-indeed "voting booths" are not even mentioned. In Connecticut and New Jersey the voter usually brings his ballot with him already prepared, but in order to place it in the official envelope he must retire for a moment to a voting-booth or room provided for this purpose, and, in so doing, escape from the sight of anyone who may have been watching him. Where this is not provided for, it is obviously possible, for any one who may be interested, to observe whether a ballot given to the voter outside the polling place is deposited by him or not.

To return to the forty States (including Tennessee) and one territory which have provided for an official "blanket" ballot-the laws of these States may be grouped most readily (1) according to the system of arranging the names of the candidates on the ballot, and (2) according to the presence or absence of any special provision for voting a straight ticket.

Twenty-seven States ${ }^{\gamma}$ and the territory of Arizona have the so-called "party column" form of ballot; that is, one on which the names of all the candidates of each party are grouped in a vertical column under the party name or emblem, the several party columns being parallel and arranged in order from left to right, usually according to the size of the vote cast by each party at the last election, or to some other prescribed rule. The names of the several candidates for each office are arranged as nearly as possible in a horizontal line across the ballot, each one in its proper column, under the title of the office. Commonly both name and emblem are placed at the top of each column, but in twelve states, ${ }^{8}$ no emblems are used.

7 Ala., Calif., Del., Idaho, Ill., Ind., Ia., Kan., Ky., La., Me., Mich., Mon., N. Hamp., N. Y., N. Dak., O., Okl., R. I., S. Dak., Tex., Utah, Vt., Wash., W. Va., Wis., and Wy.

${ }^{8}$ Calif., Ill., Ia., Me., Mont., N. Dak., S. Dak., Tex., Vt., Wash., Wis., and Wy. 
The other thirteen of the "blanket ballot" States ${ }^{9}$ use what is generally known as the "Massachusetts ballot"-Massachusetts having been the first State to adopt this form, and having retained it, with only minor changes, ever since. Under this system the names of all the candidates for each office, followed usually by the names of the parties which they represent, are grouped together in a short, vertical column under the title of the office, the several groups being placed one below another on a long, narrow ballot, or, where the number of offices to be voted for is very great, in two or more parallel columns. ${ }^{10}$ In six out of the thirteen States the law provides that the names of the candidates shall be arranged under the title of each office in alphabetical order, according to the surnames. ${ }^{11}$ In three States the arrangement of the names of the party candidates under each office is according to the vote cast by the several parties at the last preceding election, the name of the candidate of the party which cast the largest vote being placed at the top, the name of the candidate of the party which cast the next largest vote, second, and so on. ${ }^{12}$ In the other four States no particular method of arrangement is prescribed..$^{13}$

The names of candidates for presidential electors of each party are usually grouped together, and with each such group the names of the candidates of the same parties for president and vice-president are usually printed. In six out of the thirteen States it is provided that a single cross

'Ark., Col., Fla., Md., Mass., Miss., Minn., Neb., Nev., Ore., Penn., Tenn. (for the portions of the State above-mentioned), and Va.

${ }^{10}$ Several States always employ this latter form.

${ }^{11}$ Col., Md., (Laws 1908, ch. 737, preseribes this arrangement for the city of Baltimore and twelve counties, but fixes no special arrangement of the names under each office for the other eleven counties), Mass., Nev., Ore., and Tenn.

${ }^{12}$ Minn., Neb., and Penn., La., Minn., however, it is provided that "whenever two or more persons are to be elected to the same office (except the office of presidential elector), the names of all candidates of the several political parties for such office shall be so alternated on the ballots used in each election district that they shall appear thereon substantially an equal number of times at the top, at the bottom, and in each intermediate place, if any, of the list or group in which they belong." (L. 1901, ch. 88 S. 3.)

${ }^{13}$ In Arkansas no particular arrangement of names under each office is provided for. In Florida it is merely provided that "the names of all candidates for the same office shall be printed together, irrespective of party." In Mississippi the arrangement of the names is left to the discretion of the officer charged with printing the ballots, but the secretary of state, with the approval of the governor, is to prescribe a form which is to be followed, in general, as nearly as possible in all parts of the State. In Virginia the names are to be arranged under the title of each office, "in due and orderly succession." 
$(X)$ mark opposite the name of the candidate for president and vicepresident shall be counted as a vote for each of the electors of the same party. ${ }^{14}$

It is often specifically provided, with the "Massachusetts" form of ballot, that the name of any candidate shall appear on the ballot but once, followed by the designation of the party or principle which he represents. In six States ${ }^{15}$ it is further provided that, if a candidate is nominated for the same office by more than one party or group of voters, the name of each such party or group shall be printed after his name. In Minnesota, however, the law provides that no person "shall be named on the official ballot as the candidate of more than one party, or of any party other than that whose certificate of his nomination was first properly filed." In Florida, Mississippi, Tennessee and Virginia, and in certain counties in Maryland, no party designations of any sort are previded for.

It may be said, in general, that the varieties of "Massachusetts ballot" in use in the southern States are much less thoroughly developed-represent a more rudimentary type-than those, for example, of Massachusetts, Minnesota and Oregon. Probably this is due to the fact that of late years interest in these States has naturally been centered far more on the primary, than on the general, election.

In conjunction with the "Massachusetts ballot," and with the proviso that the candidate's name be followed by the names of all parties or groups which have duly nominated him for the same office, the rule that the name of any candidate shall appear in but one place on the ballot is eminently fair. When, however, as is the case in fourteen States ${ }^{18}$ this same rule is adopted in conjunction with a "party column" ballot, the combination is in many ways objectionable. ${ }^{17}$ Its result is greatly to

${ }^{14}$ Md., Mass., Minn., Neb., Penn., and Va. In the last-named State the voter is to scratch out the names of the candidates for president and vice-president of all parties which he does not want to vote for, and this counts as a vote for all electors of that party the candidates of which for president and vice-president he leaves unscratched.

A similar provision, that a whole list of presidential electors may be voted for by a single cross $\times$ mark, is found in the laws of the following States which have the "party column" form of ballot: N. Hamp., N. Dak., R. I., and Wis.

${ }^{15} \mathrm{Col}$., $\mathrm{Md}$. (in the city of Baltimore and twelve counties; in the other eleven counties no party designations appear upon the ballot), Mass., Neb., Ore., and Penn.

${ }^{18}$ Idaho, Ind., Ia., Kan., Ky., Mich., Mont., N. Dak., S. Dak., Tex., Vt., Wash., Wis., and Wy.

${ }_{17}$ This applies also to the Minnesota provision, above-mentioned, that the name of a candidate shall be followed by the name of not more than one party. 
hamper "fusion" movements, and the non-partisan election of judges, by preventing the endorsement, by one party or independent group, of candidates nominated by another, and the printing of such candidates' names in two or more columns on the ballot. In Ohio a law containing this provision was repealed, by the strenuous efforts of municipal reform associations, in 1908; but at present there is danger of its repassage. In New York a bill which attempted to introduce it in the case of all except judicial candidates passed both houses of the legislature in 1908, but was vetoed by Governor Hughes. In his veto message the Governor said: "This measure is wholly indefensible. Undoubtedly one of the criticisms of the present form of ballot is that candidates' names frequently appear in several columns, but the remedy is to change the form of ballot and to abolish the party column. In other words, we should have a simplified ballot in which the names of the candidates for the respective offices should appear but once, grouped under the names of the offices. But as long as we retain the present form of ballot with its party columns, it would be a grave injustice to prohibit a candidate's name from appearing in more than one column."

In Montana this provision was first introduced into the present law in 1907 , and it is said to be popular. It is also said in other States that such a rule prevents secret deals by party "bosses" to secure for their candidates the endorsement of minor parties, especially for the lessimportant places on local tickets. The answer to this seems to be that of Governor Hughes-that the proper remedy for such evils is the adoption of the "Massachusetts" form of ballot.

One of the most important features, according to the presence or absence of which the several forms of ballot may be grouped, is a special provision of any sort for a "straight ticket" vote. Since the chief object of the "party column" ballot is to facilitate the voting of a "straight ticket," while that of the "Massachusetts" ballot is to make the voters stop and think about each office in turn, it is natural that most of the States which have the former type of ballot provide specifically for "straight ticket" voting and that most of those which have the latter do not. Among the "party column" States, however, two-Iowa and Montana-have no such provision, and for this reason their form of ballot is, perhaps, in practice, nearer to the "Massachusetts," than to the regular "party-column" type. A bill providing for such a half-way step toward the "Massachusetts ballot" has been several times introduced in New York State. Among the "Massachusetts ballot" States, on the other hand, three out of the thirteen-Colorado, Nebraska and 
Pennsylvania - provide a special method of voting a "straight ticket"Nebraska and Pennsylvania by a row of party circles or squares, and Colorado by the following formula, printed across the top of the ballot: "I hereby vote a straight . . . ticket, except where I have marked opposite the name of some other candidate," preceded by the instruction: "To vote a straight party ticket, write within the blank space immediately hereunder the name of the party you wish to vote for." So utterly alien are these provisions to the true purpose of the "Massachusetts ballot" that the States whose laws contain them cannot properly be placed in the same class with the other ten "Massachusetts ballot" States, but must be considered as having a hybrid form of ballot which, in practice, is nearer that of the "party-column" States.

In considering these two most common forms of ballot, it is interesting to trace briefly their relative gains and losses since 1889 . The first laws establishing an official "blanket" ballot in this country commonly provided for the true "Australian" form, although a number of States adopted the "party column" modificatlon from the start. As the system spread, however, this latter form became the more popular, chiefly because it was less objectionable to the party organizations. Moreover, six States which had originally adopted the "Massachusetts ballot" changed over before 1905 to the "party-column" form. ${ }^{18}$ On the other hand, at least four States which started with the "party column" ballot -or which at one time adopted this form-have changed over to the "Massachusetts ballot."18 There is, furthermore, in a number of States at the present time a strong movement for the adoption of the "Massachusetts ballot" in place of the "party column" form. In New York State Governor Hughes has advocated this change for several years, and the sentiment in favor of it is steadily increasing. In Ohio the "Massachusetts" form was adopted in 1908 for ballots used in the election of

${ }^{18} \mathrm{~N}$. Hamp., in 1897, La., in 1898, Calif. in 1899, Mont., in 1901, Ala., in 1903, and R. I., in 1905

${ }^{18}$ Col., in 1894, Neb., in 1899, Md., in 1901, and Penn., in 1903. Neb., first adopted the "Massachusetts ballot" in 1891; in 1897 it substituted the "party column" form; and in 1899 it changed back again. Penn. adopted in 1891 a combination of two forms- " party column" for candidates of parties which had polled at least 3 per cent of the vote at the last election, and "Massachusetts" for all other candidates. In 1893 it changed to a straight "party column" ballot, and in 1903 to the "Massachusetts" form. It is only fair to note, however, that Col., Neb., and Penn., all retain, in conjunction with the "Massachusetts Ballot," a special provision for voting a "straight ticket," and that in Md., the value of this form of ballot is very much reduced by the various tricks and devices which have been added to it, in certain parts of the State where there is a large negro vote. 
members of boards of education, and there is a strong demand for its extension to municipal elections. In Kansas a "Massachusetts ballot" bill passed the lower house this year, and next year the Republican party will probably be pledged to its enactment. In New Jersey the ballot law commission above mentioned introduced a bill codifying the whole election law of the State, and adopting the "Massachusetts" form of ballot. This bill failed to pass, and this winter another bill was introduced, providing for a blanket, "party-column" ballot, with the "Massachusetts" form of ballot as an alternative. This bill was also defeated, but the question will continue to be agitated.

The outside of the ballot in practically all the "blanket ballot" States contains the words "official ballot," and usually, in addition to this, the designation of the polling place at which the ballot is to be used, and the date of the election. Often a facsimile of the signature of the officer charged with printing the ballots is provided for. The ballot must always be so folded that these markings are left visible. This requirement is to prevent the casting of any but official ballots.

In order further to insure that the ballot finally deposited by the voter shall be none other than the one received by him from the election officer, it is sometimes provided that the latter write his initials upon the back of it before handing it to the voter. A better system, and the one most generally in use, is that of numbering all the ballots consecutively, entering the number of each ballot upon the poll-book, opposite the name of the voter to whom it is given, at the moment at which it is handed to him, and comparing this number with that of the ballot returned by him before such ballot is deposited.

Where this latter method is employed, however, it is very important that the numbers be printed or written, not on the ballot itself, but upon a detachable stub, which is to be torn off before the ballot is finally deposited in the ballot box, and itself destroyed, or preserved in some other receptacle. Where the numbers are written on the ballots themselves a method is furnished by which the party watchers of the count, or the election officers acting in behalf of corrupt party leaders, can determine afterwards by whom they were cast-the one thing, of course, above all others, which the Australian ballot system is designed to avoid. A proper system of consecutive numbering has the further advantage-where the law is honestly enforced-of preventing ballotbox stuffing, the exact number of ballots lawfully cast being readily ascertainable. The same end is attained-though less satisfactorilyby merely checking off the name of each voter on the poll-book as he deposits his ballot. 